\title{
Price Competitiveness of International Tourism Destinations and Tourism Demand, Tourism Receipts Relationship
}

\author{
Ramazan GÖRAL \\ Asst.Prof. Lecturer at Ali Akkanat Tourism Faculty Selçuk University, Beyşehir/Konya TURKEY. \\ trgoral@selcuk.edu.tr.
}

\begin{abstract}
The competitiveness of an industry is a critical determinant of how well it performs in world markets. The potential for any country's tourism industry to develop will depend substantially on its ability to maintain competitive advantage in its delivery of goods and services to visitors. Competitiveness is a general concept that encompasses price differentials coupled with exchange rate movements, productivity levels of various components of the tourist industry and qualitative factors affecting the attractiveness or otherwise of a destination. Given some evidence on the price sensitivity of the demand for travel, destinations need to monitor their price competitiveness relative to alternate locations. Changing costs are among the most important factors influencing the choice of a destination with prices being an essential component in the overall tourism competitiveness of a destination. The aims of this study are; first, to demonstrate the country's tourism price competitiveness rank; second, examine the relationship between price competitiveness and tourism demand and also with tourism receipts.
\end{abstract}

Keywords: Competitiveness, Tourism Price Competitiveness

\section{Introduction}

The competitive capacity of an industry is an important indicator of its performance in the world market (Crouch and Ritchie 1999). Development potential of tourism potential of any country mostly depends on its protection ability of competition in product and services presenting to visitors. Competitive capacity is a general concept that involves price differences related to exchange rates actions, efficiency levels of various compounds of tourism industry and other factors affecting attractiveness of destination (Dwyer,Forsyth and Rao,2002, 328). We can classify the factors explained here that identify competitive capacity of tourism as below (Dwyer,Forsyth and Rao,2001, 3).

a. Socio-economic and Demographic Factors; define compounds such as population, income status of country, leisure time, education, profession etc.

b. Qualitative Factors; contain variables such as touristic attractiveness, image, quality of touristic services, marketing and introducing of destination, cultural ties etc.

c. Price Factor; forms with tourism costs charging to tourist, transportation costs to destinations and from destination to accomodation as well as basic touristic costs (accomodation, refreshments, tour services, entertainment etc.). Both two costs affect decision of travel.

Price competitive capacity is an important compound of competitive capacity of general tourism of a country or a destination. There is prevalent communion about that prices are one of the most important criterions regarding if travelling is done or not or done where to (Forsyth, Dwyer,2009). Because of the importance of prices in travelling decisions, price competitive capacity of international destinations is evaluated by four data set ( ticket taxes and airport charges, national purchasing 
power parity prices, fuel price levels and the hotel price index) prepared by World Economic Forum (WEF) in Travel \&Tourism Competitiveness Index (TTCl) study (WEF,2015).

Forming Travel \&Tourism Competitiveness Index (TTCl) helps tourism shareholders in both public and private sectors recognizing basic weakness and strong sides of destinations. It shows opportunities regarding to development of tourism and provides information towards forming strategies against possible threats towards travels done in the future (Forsyth,Dwyer,2009). In addition the focus of this study is price competitiveness of a country or a destination.

In TTCI report of WEF (2015) a comparison was done by forming price competitive capacity index about 138 country. The countries were ordered according to their index values. There are many studies done towards sensibility of tourism demand for price (Forsyth,Dwyer,2009). In this scope there must be a correlation between WEF Tourism Price Competitive Index order of different countries and the number of tourists visiting those countries as well as their tourism income. In the study the presence of this relation is evaluated.

\section{Tourism Price Competitiveness}

Price competitiveness is accepted as one of the important factors that forms competitive superiority of a specific destination (Falzon,2011,1081). The focus of tourism price competitiveness is defining of prices of goods and services purchased by tourist in some common currency (Forsyth, Dwyer,2009). According to Dwyer et al.(2001), for a tourism country or a region as it is compared to its rivals, being successful by showing development and acquiring competition power is related with competitive structure level of price of goods in its tourism sector. Price competitiveness of destination stands on price competitiveness in sub sectors providing goods and service to visitors (Dwyer,Forsyth and Rao,2001).

Various factors affect price competitiveness of destination in various ways (Forsyth, Dwyer,2009). The important ones among these factors are presented below;

Exchange Rates: Exchange rate is the most leading factor that affect tourism competitive power. If the Exchange rate of a country increases when other factors are equal, this affects the competitive power of country in negative way. Exchange rates can be used for definition of compared price levels of country of residence with other countries.

Inflation and General Price Levels: An increase in general price level in a country can reduce the advantage obtained with Exchange rate. An increse in general price levels will cause increase in costs of touristic goods and services

Labour Cost: These costs are basic determiner of long term price competition superiority in tourism. In countries that low wages are paid, the prices of goods and services are also in tendency of being low.

Productivity Level of Tourism Sector: Besides output prices reflect input (especially labour) prices, they are also an indicator of sector productivity level. If tourism industry productivity of a country having high income level is higher when compared to its rivals having low income level, countries having high income level can have more price competitive power.

Increase in Export and Dutch Disease: Structral changes due to changes in Exchange rates can affect competitive power of tourism sector. The most important effect due to structural changes is Dutch Disease which is an overvaluation of currency rate of a country having an important source.

Taxes: Taxes especially indirect taxes increase the price of goods and services purchased by tourists. This situation can also affect competitive power in negative way.

Infrastructure Cost: Toll roads, airport taxes, various denotions etc. are defined with infrastructure costs. These costs increase costs that form touristic product bundle.

Fuel Prices: Fuel is an important income item among touristic goods and services. So it can be said that fuel prices have an important effect on torism price competition. 
Environmental Payments: Tourism sector has increasingly been liable to environmental payments. Noise fee taken from airports, Carbon Emission Trade Plan expenses can be given as example for these payments. Since increase in these payments will cause increase in general levels of goods and services, they can affect price competition in negative way.

In decision of choosing destination tourists take prices forming comperative cost of living between origin destaination and alternative destinations into consideration. In determining of price competitive power of a destination two types of prices should be taken into consideration. The first one is comperative price between recipient (destination) and origin country. The second one is comperative price between different rival destinations that form effect of cost of living (Forsyth, Dwyer,2009).

Tourists make some evaluations about rival destinations before choosing any destination. They compare costs of living between choosing destination with other rival destinations. If costs of living of destination is higher that the ones in other destinations, preferrence of alternative destinations can be possible. That is, more than one destiantion alternatives having suitable costs can be obtained when they compare touristic costs with origin country (Song and Witt 2000). As a result of this, opportunity can be provided to make a choice between alternative destinations as well as foreign and domestic tourism.

Tourism demand is sensible to price factors (Crouch 1994; Lim 2006). There are many studies done regarding this subject. For example one of the price factors in price flexibility. The people of developed countries having opportunity of travel experience in their borders are more sensible to price flexibility as international travel attitude than the ones coming from geographically small countries and having limited holiday choices (Little 1980).If the attractiveness of destination have unique property, price flexibility of demand is less (Edwards 1995). Low demand price flexibility can also be expected for diffirentiated destinations. Due to differentaited destination strategy it was observed that tourists have become less sensible to price in time (Crouch 1994). High price flexibility of tourism demand is associated with destinations being equal rivals to eachother (De Mello et al. 2002).

Relative price variable that is used in Tourism demand is the price index rate of consumer between origin country and recipient country and determined by dual Exchange rate. Higher Exchange rate in favour of currency of origin country can cause travelling of more tourist from origin country to destination (Rosensweig 1986). The competition between destinations has positive effect on international tourism demand. That means, price increase in destination will increase tourism demand to alternative destination (Lim 2006).

Because of given importance to price competition, price competition indexes were developed. So it is possible for tourists to compare the prices of goods and services in different countries they purchased for touristic reasons. Tourism price competition indexes and price indicators used in these indexes show important differences. In fact these differences provide important benefits in terms of clearing up different sides of competitive power and making measurements (Dwyer,Forsyth and Rao,2001).

\section{Theoretical Frame and Methodology}

In this study related datas and knowledge was reached with data collection tool from subsidiary source. These knowledge and datas mostly stands on Tourism Price Competition Index in TTCI report published by WEF in 2015.

In the past it was hard to obtain price datas that would make comparisons towards price competition between countries. However recently it is possible to reach comprehensive data sources that will make price comprehension between countries. Especially the reports that World Bank prepared in scope of International Comparison Program (ICP) is an important source in reaching price datas. In ICP reports the prices regarding goods and services of developed and developing many countries in chosen years were gathered comprehensively. In ICP report, since there are many datas such as purchanising power parity (PPP), product prices in local currency, product prices in USA \$ etc. that are used in forming of price competition power indexes, it is an important source in calculation of price competition index. In TTCl (2015) report prepared by WEF, Tourism Price Index was calculated by benefitting from ICP. Here the aim is the measuring of tourism price competition between countries and providing current datas. In this study of WEF four different price indicator was used. One of these indicators comparative purchasing power parity of countries (PPP). PPP is a measure that shows the cost of goods and services in country in terms of USA \$. PPP is a good scale to determine general price levels in different countries however it is not specifically towards touristic products. In order to compansate this missing, in WEF 
price competition index three price datas towards touristic products (ticket taxes and airport charges, national purchasing power parity prices, fuel price levels and the hotel price index) apart from PPP were taken into evaluation (WEF,2015).

In order to make evaluation of price competition power towards tourism sector in different countries, price datas such as fuel prices, hotel prices etc. should be taken into consideration. As these datas can be used in calculation directly, they can also become more beneficial for tourism by using them with more general indicators suuch as purchasing power parity. So by benefitting from actual and easily obtained price indicator datas, a price index for tourism in different contries can be obtained (Forsyth, Dwyer,2009,13).

In this study by using tourism price competition index datas that WEF calculated by using PPP, ticket taxes and airport charges, fuel price levels and the hotel price datas belong to different countries if there is a relation between international tourism income of countries and their tourist numbers was evaluated. In the evaluation correlation analysis was done by using SPSS programme.

\section{Findings}

In Table 1 according to WEF (2015) report, general competition index (TTCI) of countries according to tourism price index order, tourist numbers and tourism income datas of countries of 2013 are placed. In Tourism Price Competition Index in terms of Price Competition Capacity as Iran $(6,62)$ places in the first rank, Egypt $(6,19)$ in the second rank, Indonesia $(6,11)$ is in the third rank, Switzerland $(2,57)$, England $(2,75)$ and France $(2,57)$ place in the last ranks.

In terms of foreign tourists in 2013 as France (84726) places in the first rank, the USA (69768) in the second rank, Spain (60661) in the third rank, Guinea, Sierra Leone and Moldova place in the last ranks.

In terms of tourism income in 2013 as the USA (173.130 M.US\$) places in the first rank, Spain (62565 M.US\$) in the second rank, France (56686M.US\$) in the third rank, Guinea, Burindi and Gabon place in the last ranks.

Table 1. General Competition Index, Tourism Price Index, Tourist Number and Tourism Income of Countries

\begin{tabular}{|l|l|l|l|l|l|l|l|l|l|l|l|}
\hline $\begin{array}{l}\text { Ran } \\
\text { k }\end{array}$ & Countrys & $\begin{array}{l}\text { TTC } \\
\text { I }\end{array}$ & $\begin{array}{l}\text { Tourism } \\
\text { Price } \\
\text { Index(TPCI } \\
\text { ) }\end{array}$ & $\begin{array}{l}\text { Arrivals } \\
\text { (Thousands } \\
\text { ) }\end{array}$ & $\begin{array}{l}\text { Receipt } \\
\text { S } \\
\text { (Inboun } \\
\text { d US\$ } \$ \\
\text { Millions) }\end{array}$ & $\begin{array}{l}\text { Ran } \\
\text { k }\end{array}$ & Countrys & $\begin{array}{l}\text { TTC } \\
\text { I }\end{array}$ & $\begin{array}{l}\text { Tourism } \\
\text { Price } \\
\text { index(TPCI } \\
\text { ) }\end{array}$ & $\begin{array}{l}\text { Arrivals } \\
\text { (Thousands } \\
\text { ) }\end{array}$ & $\begin{array}{l}\text { Receipt } \\
\text { s } \\
\text { (Inboun } \\
\text { d US } \\
\text { Millions) }\end{array}$ \\
\hline 1 & Iran & 3,32 & 6,62 & 4769 & 1294 & 47 & Lao PDR & 3,33 & 4,93 & 2510 & 596 \\
\hline 2 & Egypt & 3,49 & 6,19 & 9174 & 6047 & 48 & Kazakhstan & 3,48 & 4,92 & 4926 & 1344 \\
\hline 3 & Indonesia & 4,04 & 6,11 & 8802 & 9119 & 49 & Zambia & 3,22 & 4,92 & 915 & 155 \\
\hline 4 & Yemen & 2,62 & 5,99 & 990 & 940 & 50 & El Salvador & 3,41 & 4,91 & 1283 & 621 \\
\hline 5 & Gambia & 3,2 & 5,9 & 171 & 88 & 51 & $\begin{array}{l}\text { Madagasca } \\
\text { r }\end{array}$ & 2,99 & 4,91 & 196 & 321 \\
\hline 6 & Malaysia & 4,41 & 5,76 & 25715 & 21496 & 52 & Romania & 3,78 & 4,89 & 1715 & 1590 \\
\hline 7 & Tunisia & 3,54 & 5,61 & 6269 & 2190 & 53 & $\begin{array}{l}\text { Sierra } \\
\text { Leone }\end{array}$ & 2,77 & 4,89 & 81 & 59 \\
\hline 8 & India & 4,02 & 5,59 & 6968 & 18397 & 54 & Mexico & 4,36 & 4,88 & 24151 & 13949 \\
\hline 9 & Pakistan & 2,92 & 5,59 & 966 & 288 & 55 & Lithuania & 3,88 & 4,87 & 2012 & 1467 \\
\hline 10 & algeria & 2,93 & 5,5 & 2733 & 217 & 56 & Tanzania & 3,35 & 4,87 & 1063 & 1880 \\
\hline 11 & $\begin{array}{l}\text { Saudi } \\
\text { Arabia }\end{array}$ & 3,80 & 5,49 & 13380 & 7651 & 57 & Latvia & 4,01 & 4,84 & 1536 & 864 \\
\hline 12 & Swaziland & 3,20 & 5,49 & 968 & 30 & 58 & Lebanon & 3,35 & 4,84 & 1274 & 5870 \\
\hline 13 & angola & 2,60 & 5,46 & 650 & 1234 & 59 & Cameroon & 2,95 & 4,83 & 912 & 349 \\
\hline 14 & Botswana & 3,42 & 5,44 & 2145 & 44,9 & 60 & Puerto Rico & 3,91 & 4,82 & 3200 & 3334 \\
\hline
\end{tabular}




\begin{tabular}{|c|c|c|c|c|c|c|c|c|c|c|c|}
\hline 15 & $\begin{array}{l}\text { Kyrgyz } \\
\text { Republic } \\
\end{array}$ & 3,08 & 5,37 & 3076 & 530 & 61 & Uganda & 3,11 & 4,82 & 1206 & 1184 \\
\hline 16 & Guatemala & 3,51 & 5,35 & 1331 & 1480 & 62 & Moldova & 3,16 & 4,80 & 96 & 226 \\
\hline 17 & $\begin{array}{l}\text { Trinidad } \\
\text { and } \\
\text { Tobago } \\
\end{array}$ & 3,71 & 5,34 & 434 & 472 & 63 & Azerbaijan & 3,48 & 4,78 & 2160 & 2432 \\
\hline 18 & Bahrain & 3,85 & 5,33 & 1069 & 1051 & 64 & Georgia & 3,68 & 4,76 & 2065 & 1720 \\
\hline 19 & Oman & 3,79 & 5,33 & 1551 & 1222 & 65 & Malawi & 2,90 & 4,69 & 770 & 34 \\
\hline 20 & Qatar & 4,09 & 5,33 & 2611 & 3456 & 66 & Sri Lanka & 3,80 & 4,67 & 1275 & 1715 \\
\hline 21 & Bolivia & 3,29 & 5,32 & 798 & 573,2 & 67 & Ethiopia & 3,03 & 4,65 & 681 & 619 \\
\hline 22 & Vietnam & 3,60 & 5,30 & 7572 & 7503 & 68 & Jordan & 3,59 & 4,63 & 3945 & 4117 \\
\hline 23 & Nepal & 3,27 & 5,29 & 798 & 436 & 69 & Venezuela & 3,18 & 4,63 & 986 & 844 \\
\hline 24 & Philippines & 3,63 & 5,28 & 4681 & 4691 & 70 & Estonia & 4,22 & 4,62 & 2873 & 1398 \\
\hline 25 & Guyana & 3,26 & 5,27 & 177 & 77 & 71 & Burkina Fa. & 2,67 & 4,61 & 218 & 133 \\
\hline 26 & Lesotho & 2,82 & 5,27 & 320 & 46 & 72 & Rwanda & 3,32 & 4,61 & 864 & 294 \\
\hline 27 & Nicaragua & 3,37 & 5,26 & 1229 & 417 & 73 & Hungary & 4,14 & 4,6 & 10675 & 5272 \\
\hline 28 & Mongolia & 3,31 & 5,25 & 418 & 189 & 74 & Armeni & 3,42 & 4,58 & 1204 & 987 \\
\hline 29 & Namibia & 3,69 & 5,20 & 1176 & 409 & 75 & Serbia & 3,34 & 4,56 & 922 & 1053 \\
\hline 30 & Haiti & 2,75 & 5,17 & 420 & 568 & 76 & Macedonia & 3,50 & 4,55 & 400 & 267 \\
\hline 31 & Panama & 4,28 & 5,15 & 1658 & 3201 & 77 & Brazil & 4,37 & 4,51 & 5813 & 6704 \\
\hline 32 & Honduras & 3,41 & 5,14 & 863 & 608 & 78 & Slovak Pub. & 3,84 & 4,51 & 6235 & 2556 \\
\hline 33 & China & 4,54 & 5,1 & 55686 & 51664 & 79 & Kenya & 3,58 & 4,50 & 1433 & 881 \\
\hline 34 & Bulgaria & 4,05 & 5,08 & 6897 & 4059 & 80 & Suriname & 3,28 & 4,50 & 249 & 84 \\
\hline 35 & Thailand & 4,26 & 5,06 & 26547 & 42080 & 81 & Cape Verde & 3,46 & 4,48 & 503 & 462 \\
\hline 36 & Kuwait & 3,26 & 5,04 & 307 & 298 & 82 & Montenegro & 3,75 & 4,48 & 1324 & 884 \\
\hline 37 & $\begin{array}{l}\text { Taiwan, } \\
\text { China } \\
\end{array}$ & 4,35 & \begin{tabular}{|l}
5,04 \\
\end{tabular} & 8016 & 12323 & 83 & Colombia & 3,73 & 4,47 & 2288 & 3611 \\
\hline 38 & Burindi & 2,7 & 5,02 & 142 & 1,5 & 84 & $\begin{array}{l}\text { Czech } \\
\text { Republic } \\
\end{array}$ & 4,22 & 4,47 & 9004 & 7050 \\
\hline 39 & Cambodia & 3,24 & 5 & 4210 & 2659 & 85 & Cote dlvoire & 3,05 & 4,46 & 289 & 141 \\
\hline 40 & Gabon & 2,92 & 4,99 & 187 & 9 & 86 & Chile & 4,04 & 4,44 & 3576 & 2219 \\
\hline 41 & $\begin{array}{l}\text { Russian } \\
\text { Fed. }\end{array}$ & 4,08 & 4,99 & 28356 & 11988 & 87 & Bangladesh & 2,90 & 4,43 & 148 & 128 \\
\hline 42 & $\begin{array}{l}\text { South } \\
\text { Africa }\end{array}$ & 4,08 & 4,99 & 9537 & 9238 & 88 & Costa Rica & 4,1 & 4,4 & 2428 & 2664 \\
\hline 43 & Zimbabwe & 3,09 & 4,96 & 1833 & 851 & 89 & Albania & 3,22 & 4,38 & 2857 & 1473 \\
\hline 44 & $\begin{array}{l}\text { United Arab } \\
\text { Em } \\
\end{array}$ & 4,43 & 4,95 & 9990 & 11564 & 90 & Nigeria & 2,79 & 4,38 & 600 & 543 \\
\hline 45 & Morocco & 3,81 & 4,94 & 10046 & 6850 & 91 & Turkey & 4,08 & 4,37 & 37795 & 27997 \\
\hline 46 & Poland & 4,08 & 4,94 & 15800 & 10938 & 92 & $\begin{array}{l}\text { Mozambiqu } \\
\mathrm{e}\end{array}$ & 2,81 & 4,36 & 1886 & 241 \\
\hline
\end{tabular}

\begin{tabular}{|l|l|l|l|l|l|}
\hline Rank & Countrys & TTCl & $\begin{array}{l}\text { Tourism Price } \\
\text { Index(TPCl) }\end{array}$ & $\begin{array}{l}\text { Arrivals } \\
\text { (Thousands) }\end{array}$ & $\begin{array}{l}\text { Receipts } \\
\text { (Inbound } \\
\text { US\$ } \\
\text { Millions) }\end{array}$ \\
\hline 93 & Slovenia & 4,17 & 4,34 & 2259 & 2709 \\
\hline 94 & Ghana & 3,01 & 4,32 & 931 & 914 \\
\hline
\end{tabular}




\begin{tabular}{|c|c|c|c|c|c|}
\hline 95 & Guinea & 2,58 & 4,32 & 56 & 1,4 \\
\hline 96 & Jamaica & 3,59 & 4,29 & 2008 & 2074 \\
\hline 97 & Paraguay & 3,11 & 4,29 & 610 & 273 \\
\hline 98 & Croatia & 4,3 & 4,28 & 10955 & 9566 \\
\hline 99 & United States & 5,12 & 4,27 & 69768 & 173130 \\
\hline 100 & Mali & 2,87 & 4,24 & 142 & 210 \\
\hline 101 & Portugal & 4,64 & 4,23 & 8301 & 12284 \\
\hline 102 & Malta & 4,16 & 4,22 & 1582 & 1404 \\
\hline 103 & Spain & 5,31 & 4,22 & 60661 & 62565 \\
\hline 104 & Uruguay & 3,65 & 4,20 & 2684 & 1920 \\
\hline 105 & Luxembourg & 4,38 & 4,10 & 944 & 4843 \\
\hline 106 & Korea, Rep. & 4,37 & 4,06 & 12176 & 14629 \\
\hline 107 & Dominican R. & 3,5 & 4,02 & 4690 & 5065 \\
\hline 108 & Argentina & 3,90 & 3,97 & 5935 & 4627 \\
\hline 109 & Cyprus & 4,25 & 3,97 & 2405 & 2917 \\
\hline 110 & Greece & 4,36 & 3,93 & 17920 & 16139 \\
\hline 111 & Mauritius & 3,90 & 3,91 & 993 & 1321 \\
\hline 112 & Peru & 3,88 & 3,90 & 3164 & 3009 \\
\hline 113 & Singapore & 4,86 & 3,82 & 11898 & 19057 \\
\hline 114 & New Zealand & 4,64 & 3,77 & 2629 & 7472 \\
\hline 115 & Chad & 2,43 & 3,76 & 100 & 25 \\
\hline 116 & Japan & 4,94 & 3,75 & 10364 & 15131 \\
\hline 117 & belgium & 4,51 & 3,73 & 7976 & 14268 \\
\hline 118 & Finland & 4,47 & 3,71 & 2797 & 4049 \\
\hline 119 & Ireland & 4,53 & 3,69 & 8260 & 4476 \\
\hline 120 & Seychelles & 4,00 & 3,68 & 230 & 344 \\
\hline 121 & Canada & 4,92 & 3,63 & 16590 & 17656 \\
\hline 122 & Myanmar & 2,72 & 3,63 & 2044 & 281 \\
\hline 123 & Germany & 5,22 & 3,62 & 31545 & 41211 \\
\hline 124 & Hong kong & 4,68 & 3,59 & 25661 & 38937 \\
\hline 125 & Iceland & 4,54 & 3,59 & 807 & 1077 \\
\hline 126 & Barbados & 4,08 & 3,58 & 520 & 947 \\
\hline 127 & Netherlands & 4,67 & 3,56 & 12782 & 13779 \\
\hline 128 & Senegal & 3,14 & 3,56 & 1063 & 468 \\
\hline 129 & Austria & 4,82 & 3,49 & 25291 & 20559 \\
\hline 130 & Italy & 4,98 & 3,49 & 47704 & 43912 \\
\hline 131 & Sweden & 4,45 & 3,38 & 11635 & 11492 \\
\hline 132 & Denmark & 4,38 & 3,31 & 8557 & 6939 \\
\hline 133 & Israel & 3,66 & 3,24 & 2962 & 5666 \\
\hline 134 & Norway & 4,52 & 3,23 & 4734 & 5675 \\
\hline 135 & Australia & 4,98 & 3,06 & 6868 & 32022 \\
\hline
\end{tabular}




\begin{tabular}{|l|l|l|l|l|l|}
\hline 136 & France & 5,24 & 2,95 & 84726 & 56686 \\
\hline 137 & United King. & 5,12 & 2,73 & 31169 & 41028 \\
\hline 138 & Switzerland & 4,99 & 2,57 & 8967 & 16881 \\
\hline
\end{tabular}

Source: WEF (2015)

Correlation analysis was done by SPSS software in order to evaluate if there is a statistically significant relation between Tourism Competition Capacity Index (TTCI), Tourist number and Tourism Income (Table 2).

\section{Table 2. The Relation between TTCI with Tourist number and Tourism Income}

\begin{tabular}{|l|l|l|l|}
\hline \multicolumn{2}{|l|}{} & arrivals & receipts \\
\hline \multirow{3}{*}{ TTCl } & Pearson Correlation &, $619^{* *}$ &, $570^{* *}$ \\
\cline { 2 - 4 } & Sig. (2-tailed) &, 000 &, 000 \\
\cline { 2 - 4 } & N & 138 & 138 \\
\hline
\end{tabular}

${ }^{* *} 0,01$

As it is understood from the value of correlation analysis in Table 2, there is a statistically significant relation in positive way between Tourism Competation Index (TTCl) with Tourist number and Tourism Income. So as Competition capacity increases, tourist number and tourism income increase.

Correlation analysis was done by SPSS software in order to evaluate if there is a statistically significant relation between Tourism Price Competition Index (TPCI), Tourist number and Tourism Income of countries (Table 3).

\section{Table 3. The Relation between TPCI with Tourist number and Tourism Income}

\begin{tabular}{|l|l|l|l|}
\hline \multicolumn{2}{|l|}{} & arrivals & receipts \\
\hline \multirow{3}{*}{ TPCl } & Pearson Correlation &,$- 257^{* *}$ &,$- 254^{* *}$ \\
\cline { 2 - 4 } & Sig. (2-tailed) &, 002 &, 003 \\
\cline { 2 - 4 } & $\mathrm{N}$ & 138 & 138 \\
\hline
\end{tabular}

**0,01

As it is understood from the value of correlation analysis in Table 3, there is a statistically significant relation in negative way between Tourism Price Competation Index (TPCl) with Tourist number and Tourism Income. So Tourism Price Competation interacts inversely proportional with tourist number and tourism income.

As forming price competition index is formed, chosen destinations should be considerably rival destinations with eachother. Price competition power of a destination gains meaning exactly when compared to alternative destinations that can be chosen by visitor (Forsyth, Dwyer,2009). In this scope to eight destinations in Mediterranean Basin (Turkey, Greece, Italy, France, Spain, Egypt, Tunusia and Morocco) Price Competition with Tourist number and Tourism income analysis was done. Related destinations were chosen by using "competition cluster" logic that was presented by Kozak and Rimmington (Kozak, Rimmington,1999).

In Table $4 \mathrm{TPCl}$, Tourist number and Tourism Income regarding eight destinations in Mediterranean Basin is presented.

Table 4. TPCl, Tourist Number and Tourism Income Regarding Eight Destinations in Mediterranean Basin 


\begin{tabular}{|l|l|l|l|}
\hline Country & TPCI & $\begin{array}{l}\text { Arrivals } \\
\text { (Thousands) }\end{array}$ & $\begin{array}{l}\text { Receipts } \\
\text { (inbound US\$ } \\
\text { Millions) }\end{array}$ \\
\hline Egypt & 6,19 & 9174 & 6047 \\
\hline Greece & 3,93 & 17920 & 16139 \\
\hline Italy & 3,49 & 47704 & 43912 \\
\hline Spain & 4,22 & 60661 & 62565 \\
\hline France & 2,95 & 84726 & 56686 \\
\hline Tunisia & 5,61 & 6269 & 2190 \\
\hline Turkey & 4,37 & 37795 & 27997 \\
\hline Morocco & 4,94 & 10046 & 6850 \\
\hline
\end{tabular}

Correlation analysis was done by SPSS software in order to evaluate if there is a statistically significant relation between Tourism Competition Index (TTCl), Tourist number and Tourism Income datas regarding eight destinations in Mediterranean Basin given in Table 4 (Table 5).

Table 5. The Relation Between TPCI With Tourist Number And Tourism Income According to Rival Destinations

\begin{tabular}{|l|l|l|l|}
\hline \multicolumn{2}{|l|}{} & arrivals & receipts \\
\hline \multirow{3}{*}{ TPCl } & Pearson Correlation &,$- 810^{*}$ &,$- 767^{*}$ \\
\cline { 2 - 4 } & Sig. (2-tailed) &, 015 &, 026 \\
\cline { 2 - 4 } & $\mathrm{N}$ & 8 & 8 \\
\hline${ }^{*} 0,05$ & \multicolumn{2}{l}{}
\end{tabular}

As it is understood from the value of correlation analysis in Table 5, there is a statistically significant relation in negative way between Tourism Price Competation Index (TPCI) with Tourist number and Tourism Income of rival destinations. So Tourism Price Competation interacts inversely proportional with tourist number and tourism income.

\section{Result}

In this study by using TPCI datas in World Economic Forum TTCI report, the presence of sitatistically significant relation between price competition levels of 8 rival destinations in Mediterranean Basin with tourism incomes and tourist numbers was evaluated.

As Iran $(6,62)$, Egypt $(6,19)$, Indenosia $(6,11)$ place in the first ranks in terms of Tourism Price Competition, TPCI rank of France is 136 and its index value is $(2,95)$. In terms of tourism income, the USA that is in the first rank, itsTPCI rank is 99 and its index value is $(4,27)$ (Table 1). As it is understood from these datas and correlation analysis results tourism price competition capacity forms the part of rather comprehensive study in evaluation of general competitiveness. Although prices play role in choosing of destination, price is not the only criterion. Factors such as currency rate transactions, efficiency level of various shareholders in tourism sector and qualitative factors that affect attractiveness with price differentiations are also important in decision stage. In this scope in the study TPCI values with analysis between Tourist number and tourism income that can be considered as indicators towards touristic demand show that price competition capacity is not effective alone.

This study is important in terms of showing how secondary datas that were obtained from index and dependent indexes to introduce Tourism Price Competition Capacity Index and effective comperative analysis, should be analysed. Future researchers can make evaluations towards different destinations by following and developing methods and evaluations used in this study.

The limitation regarding this study is the validity and reliability of presented findings with this study depends to validity and reliability of TTCl datas since the datas of World Economic Forum was used in the study. 


\section{References}

Crouch, G. I. 1994. "The Study of International Tourism Demand: A Review of Findings." Journal of Travel Research 33 (1): 12-23.

Crouch, G.I, and J. R. Brent Ritchie (1999). "Competitive Tourism Destinations:Combining Theories of Comparative Advantage." Unpublished working paper, Ninth Australian Tourism and Hospitality Research Conference, February, in Adelaide, Australia.

De Mello, M., A. Pack, and M. T. Sinclair. (2002). A System of Equations Model of UK Tourism Demand in Neighbouring Countries. Applied Economics 34 (4): 509-21.

Dwyer, L. Forsyth,P.and Rao,P.(2001), PPPs and the Price Competitiveness of International Tourism Destinations, Joint World Bank-OECD Seminar on Purchasing Power Parities, Recent Advances in Methods and Applications, Washington D.C. 30 January-2 February 2001)

Dwyer, L. Forsyth,P.and Rao,P.(2002),Destination price Competitiveness: Exchange rate Changes Versus Domestic Inflation, Journal of Travel Research,Vol.40,328-336.

Edwards, A. (1995). Asia-Pacific Travel Forecasts to 2005. Research Report. London: Economist Intelligence Unit.

Falzon,J.(2011),The Price Competitive Position of Mediterranean Countries in Tourism: Evidence From The Thomson Brochure, Tourism Management,(1080-1092).

Forsyth,P.,Dwyer,L.(2009), Tourism Price Competitiveness, The Travel and Tourism Competitiveness Report 2009 World Economic Forum Geneva, Switzerland ,77-90.

The Travel and Tourism Competitiveness Report, World Economic Forum, Geneva.

Kozak, M. and Rimmington, M. (1999), "Measuring Tourist Destination Competitiveness: Conceptual Considerations and Empirical Findings", International Journal of Hospitality Management, 18(3): 273-283.

Little, J. S. (1980). International Travel in the US Balance of Payments, New England Economic Review May/June: 42-55.

Lim, C. (1999). A Meta-Analytic Review of International Tourism Demand. Journal of Travel Research 37 (3): 273-84.

Lim,C.(2006). A Survey of Tourism Demand Modelling Practice: Issues and Implications. In International Handbook on the Economics of Tourism, L. Dwyer and P. Forsyth, eds. Cheltenham, UK and Northampton, MA: Edward Elgar. 45-72.

Rosensweig, J. A. (1986). Exchange Rates and Competition for Tourists. New England Economic Review July/August: 5767.

Song, H. and S. F. Witt. (2000). Tourism Demand Modelling and Forecasting: Modern Econometric Approaches. Cambridge: Pergamon.

World Bank. 2011, Purchasing Power of Currencies: Comparing National Incomes Using ICP Data. Washington, DC: International Economics Department, World Bank.

World Economic Forum (WEF), (2015), The Travel and Tourism Competitiveness Report 2015, Geneva. 